\title{
El punzante pasado. Sobre arte, historia y memoria en el estado español
}

\author{
JuAn Vicente Aliaga \\ (Facultad de Bellas Artes, UPV) \\ The piercing past. \\ About art, history and memory in the Spanish state
}

\begin{abstract}
RESUMEN
En el texto se plantea la pregunta, $y$ se trata de ofrecer algunas respuestas, sobre la ausencia durante muchos años de trabajos artísticos surgidos en el estado español sobre el pasado histórico, y concretamente sobre el periodo de la II República, la guerra civil y la dictadura franquista. Asimismo se propone una reflexión sobre la amnesia generada en la etapa de la transición a la democracia tras la muerte de Franco.

Se estudian distintas propuestas artísticas que han abordado desde finales de los años 80 cuestiones tan lancinantes como el olvido de los represaliados por el franquismo, el papel de las mujeres durante los tiempos de guerra y el exilio, la desmemoria acerca de los campos de concentración en distintas partes de la geografía española...
\end{abstract}

PALABRAS CLAVE: Pasado reciente, Amnesia colectiva, Franco, memoria y olvido, arte actual

\section{ABSTRACT}

The lack of art works related or inspired by the historical past in spanish art is one of the main questions in this text. Particularly why some periods have been neglected: II Republic, Civil War and Franco Dictatorship. Amnesia has also been present in art when dealing with the recent transition to democracy after the death of Franco. Different art practices are perused in this text starting from the $80 \mathrm{~s}$ and up to now. These art works have dealt with different issues: the oblivion republicans suffered, the role played by women in wartime and in the exile. Also the meaning of forgetfullness on the concentration camps in different regions of Spain is taken into consideration.

\section{KEYWORDS:}

Recent past, Collective amnesia, Franco, Memory and forgetting, Art today

Una fecha reciente, el 18 de julio de 2011, ha servido de elocuente catalizador al aglutinar todo un conjunto de demonios, de miedos y de deudas pendientes en relación a la (no) asunción de unos hechos históricos. Han transcurrido ya setenta y cinco años desde el golpe de estado perpetrado por Franco y sus generales (Mola a la cabeza) y esta efeméride sigue despertando reacciones encontradas, 
mistificaciones de la historia o cuando menos evasivas y huidas por parte de algunos (poderosos) sectores de la política y la cultura españolas.

Con motivo del aniversario distintos medios de comunicación, particularmente los de pensamiento progresista, han indagado sobre el cumplimiento o no de la ley de memoria histórica (2007). De estas lecturas se desprende que la presencia de referencias a la dictadura (nombramientos o medallas de honor otorgadas a la cúspide del poder fascista) permanece en vigor en algunos ayuntamientos, verbigracia los de Valencia o Castellón, y no han sido eliminados como manda la ley, por no hablar del número de calles dedicadas a personaje facciosos y la multitud de placas que lucen el yugo y las flechas en las viviendas de protección oficial. Las resistencias son muchas y vienen todas ellas de la derecha que gobierna en municipios, diputaciones y comunidades autónomas. Una de las más sonadas es el incumplimiento de la ciudad autónoma de Melilla, gobernada por el Partido Popular, que se resistía a retirar el monumento ecuestre de Franco y numerosos recuerdos del dominio fascista. Finalmente la estatua se llevó a unos almacenes pero permanece otra del dictador en la vía pública a los pies del recinto amurallado'. También es llamativa la controversia sobre el Valle de los Caídos, la permanencia de la tumba de Franco en la basílica, la retirada de la cruz... Recientemente han sido noticia los privilegios concedidos por la Xunta de Galicia a la familia de Franco que impide las visitas al pazo de Meirás en agosto, tras un largo litigio que ha desbloqueado la contumacia de los familiares obligándoles a permitir que el pazo se abre al público una vez a la semana. ¿Por qué tantos miramientos por parte de la derecha española, por qué tanta pusilanimidad por parte del PSOE? ¿Por qué tanto apartar la vista en otros casos?

Por otro lado, puede también nombrarse la falta de voluntad para investigar sobre los juicios militares, las exhumaciones que faltan...

El balance que hacen las asociaciones de víctimas es claramente negativo aunque ha habido a mi juicio algunos avances.

En el terreno de las interpretaciones históricas, más allá del empuje que está teniendo el revisionismo (Pío Mora, César Vidal, Fernando Sánchez Dragó y otras voces) la última perla la ofrece la chapucera y tendenciosa redacción del Diccionario biográfico encargado por José María Aznar en 1999 y que ha publicado la Academia Española de la Historia. El escándalo ha sido mayúsculo, siendo el aspecto más comentado la entrada dedicada por el historiador Luis Suárez a Francisco Franco al que evita considerar como dictador.

Son estos algunos datos espigados entre los muchos disponibles que dan a entender que la historia de la guerra civil y de la dictadura continúa siendo en algunos sectores una herida abierta sujeta a vaivenes políticamente interesados. Bien es cierto que determinado episodios de la guerra civil, por ejemplo, aquellos en los que se produjeron hechos violentos ${ }^{2}$ por parte de grupos o sectores iz-

1 Véase El País, 4 de agosto de 2010. http://www.elpais.com/articulo/espana/Defensa/retira/Melilla/ultima/estatua/ecuestre/Franco/elpepuesp/20100804elpepunac_20/Tes 
quierdistas no han sido asumidos plenamente todavía en algunas aéreas del mismo o parecido ideario, pero el meollo de la cuestión estriba en que el Partido Popular, la Conferencia Episcopal y amplias fracciones de la derecha sociológica (Intereconomía, La Gaceta, Libertad digital, la COPE y un sinfín de medios) persiste en su alineamiento ideológico comprensivo hacia comportamientos que se dieron durante el pasado franquista ${ }^{3}$.

Dicho esto cabría preguntarse: ¿por qué el estudio del pasado histórico ha sido tabú durante tanto tiempo en el estado español? ¿Y por qué sigue siendo objeto de tanta controversia cuando ya se puede investigar? Por pasado histórico me refiero concretamente al periodo comprendido por la guerra civil y también por las largas décadas en las que el franquismo ejerció el poder absoluto y con él la brutal represión de los demócratas republicanos, de los grupos revolucionarios, y de otros segmentos de la población española que perdieron la guerra.

La amnesia no sólo ha afectado a los años treinta y decenios posteriores sino que comprende también la llamada transición. En este periodo se produjo la aprobación de la tan debatida Ley de amnistía de $1977^{4}$, que afectaba claramente a épocas anteriores. Importa por ello, y para evitar equívocos, definir qué se entiende por transición, un concepto sobre el que no parece haber consenso. Según Josep Ramoneda:

«es un proceso largo que tiene su origen en la incorporación de la economía española en el capitalismo internacional en la década de los sesenta y en la formación, por aquellas mismas fechas, de movimientos de resistencia política y sindical con capacidad real de movilización, y que culmina con el ingreso de España en la Unión Europea en 1986. Aunque el cambio de régimen tiene lugar entre la muerte del dictador en 1975 y la aprobación de la Constitución en 1978, difícilmente se habría producido por las vías primordialmente pacíficas en que se llevó a cabo sin la profunda transformación que la sociedad española empezó a vivir desde los años sesenta» ${ }^{5}$.

2 El historiador británico Paul Preston, que es contrario a la estrategia equivalentista, así lo ha expuesto en El holocausto español. Odio y exterminio en la guerra civil y después, Barcelona, Debate, 2011.

3 En opinión de León de la Riva, actual alcalde de Valladolid (PP) la memoria histórica fue una nefasta invención de Zapatero. Ver: http://www.publico.es/espana/387633/leon-de-la-riva-la-memoria-historica-fue-una-nefasta-invencion-de-zapatero

4 Jaime Sartorius sostiene que la ley iba dirigida a las víctimas de la dictadura: «Se trataba de amnistiar a los reprimidos por el franquismo, no a los franquistas, que ya se habían autoamnistiado, de forma que fueron los partidos de izquierda y los nacionalistas con representación parlamentaria los que tomaron la iniciativa de redactar la ley, sin que los herederos de la dictadura ni siquiera aceptaran participar en la Comisión parlamentaria, ni votaran posteriormente a favor de una ley que no les afectaba», Ver Jaime Sartorius, «La Ley de Amnistía no ampara al franquismo», El País, Madrid, 15 de marzo de 2010. p. 25.

5 «Un relato abierto», Josep Ramoneda, En transición, CCCB, Barcelona, 2007. Reproducido en el texto de ALIAGA, Juan Vicente «Lo que algunos todavía no quieren ver. Pensar el pasado y la historia reciente; recuperar políticamente la memoria histórica desde el trabajo artístico, en Ejercicios de memoria, La Panera, Lleida, 2011, pp. 9-10 
En esta definición está implícito, creo, el recuerdo de coyunturas tan violentas como aquella en que se produjeron los cinco muertos a manos de la policía en la iglesia de San Francisco de Asís en Vitoria, en 1976, la matanza de los abogados de Atocha, en 1977, y los muchos actos sangrientos perpetrados por la ultraderecha y por ETA.

Por otro lado conviene considerar que bajo el manto edulcorado de una perspectiva con ribetes hagiográficos ${ }^{6}$ la transición ha podido servir de obstáculo para remover (investigar, estudiar) determinados episodios de la historia que seguían vivos pues en ella participaron políticos de primera fila que desempeñaron un papel capital en la misma transición.

En ese sentido sería adecuado establecer una distinción entre historia y memoria por la confusión que haya podido producirse. En el primer concepto se tiene en cuenta lo estudiado y documentado respecto de los hechos ocurridos. Historia es todo lo que se ha escrito de los hechos que han sucedido a lo largo de los años. En cambio en el segundo término, memoria, se insiste sobre todo en el recuerdo evocado por los sujetos que vivieron esa historia y la han narrado o transmitido. Por ello se puede afirmar que la memoria supone la reconstrucción subjetiva del pasado. Y dicha reconstrucción puede ser individual (los recuerdos que tiene un individuo) o colectiva (los de un grupo). Ni historia ni memoria son completamente objetivas; en ellas cabe el enfoque, la interpretación, el punto de vista, más contrastado eso sí en los asuntos de historia, pero no por ello constitutivo de una verdad absoluta.

Conocer el pasado, estudiarlo, analizarlo, comprenderlo, sin ocultar datos fehacientes y comprobados, no habría de suponer caer en la sacralización del mismo. Memorias hay muchas y variadas como advierte Enzo Traverso, y un mismo hecho puede ser leído de formas harto disímiles como por ejemplo el final de la segunda guerra mundial, el 8 de mayo de $1945^{7}$, según se considere la óptica de los países occidentales, la de los de Europa del este o la de los del norte de África.

En toda sociedad democrática como es el caso de la española, aun con sus deficiencias puestas de manifiesto, entre otros sectores, por el movimiento 15-M, no puede ni debe haber una memoria de una sola pieza, monolítica. Y en realidad puede comprobarse que no la hay pese a algunas tentativas de uniformizarla o de reducirla a simplificaciones.

Dicho esto, no conviene olvidar que unas memorias han estado más presentes que otras y es palpable que la de los enterrados en las fosas comunes del fran-

${ }^{6}$ El enfoque propuesto por Victoria Prego en la serie documental en trece capítulos titulada $\mathrm{La}$ Transición, emitida por RTVE en 1996 peca claramente de reduccionista al basarse en las primeras espadas de la política española dejando de lado a la ciudadanía y a las movilizaciones populares. Contrasta la perspectiva de Prego con la ofrecida en dos partes en Después de..., de Cecilia M. y José M. Bartolomé, 1981-1983, centrada en las manifestaciones de distintos colectivos.

7 TRAVERSO, Enzo De la memòria i el seu ús crític, Barcelona, KrTu, 2008, p. 30. 
quismo ha sido ignorada y no pudo emerger hasta hace apenas una década cuando Emilio Silva recuperó los restos de su abuelo en Priaranza del Bierzo y este acto impulsó, junto con el trabajo de otras personas, en 2000, el surgimiento de las asociaciones por la recuperación de la memoria histórica.

Por ello importa dejar claras algunas premisas pues a todas luces no es aceptable la exaltación de la equidistancia en la práctica de la violencia en la guerra civil: los fascistas que dieron el golpe de estado fueron los únicos culpables del mismo, contraviniendo el orden legal emanado de las urnas como han señalado muchos historiadores ${ }^{8}$. Sin embargo, ello no es óbice para negar que hubo también actos de violencia revolucionaria en la retaguardia republicana.

Desde 2007, año de la aprobación de la denominada Ley de la memoria histórica, los medios de comunicación españoles, de distintas tendencias ideológicas, han publicado numerosos artículos sobre este asunto capital para el conocimiento del pasado y de la historia. Las posiciones siguen siendo diversas, como no podría ser de otra forma dadas las pasiones que suscita y los distintos planteamientos políticos. Entre las manifestadas se cuenta la de Joaquín Leguina ${ }^{9}$ que no parece establecer distingos entre la violencia de unos y otros; también la de Viçenc Navarro que hace hincapié en el dominio de la vida política y mediática de los descendientes de los vencedores de la Guerra Civil lo que podría explicar la resistencia en España a modificar la versión histórica hegemónica de la derecha sociológica ${ }^{10}$; y no pueden olvidarse las trabajadas aportaciones de Santos Julià, Carme Molinero, Pere Ysàs, Ricard Vinyes...

El objetivo de este texto ${ }^{11}$ está relacionado con lo referido hasta el momento pero se centra sobre todo en averiguar y conocer en la medida de lo posible por qué la recuperación de la memoria no ha sido pródiga en la esfera artística del estado español en comparación con otras disciplinas culturales (el cine, los mismos estudios de historia...). ¿Qué ha sucedido, o más bien qué ha dejado de suceder en lo relativo a la práctica artística para que pasara desapercibida por parte de los historiadores del arte, de quien ejerce el comisariado, de los críticos, de la dirección de los museos?

Estas preguntas conducen a otras: ¿cómo se lleva adelante el trabajo de hacer memoria, de practicar la anamnesis, desde la práctica artística? ¿Cuándo se inició esa tarea dentro del arte en el estado español? ¿Y qué aspectos de la historia, cargada de política, han suscitado el interés de los/as artistas? ¿Qué elementos faltan todavía por examinar? ¿Cómo explicar esa grave negligencia?

${ }^{8}$ Véase RODRIGO, Javier Hasta la raíz. Violencia durante la guerra civil y la dictadura franquista, Madrid, Alianza editorial, 2008.

9 LEGUINA, Joaquín «Enterrar a los muertos», El País, Madrid, 24 de abril de 2010, p. 31.

10 NAVARRO, Vicenç «No todos los muertos son iguales», Público, Madrid, 22 de julio de 2010.

${ }_{11}$ Para la redacción del mismo me he basado en otro texto mío titulado «Lo que algunos todavía no quieren ver. Pensar el pasado y la historia reciente; recuperar políticamente la memoria histórica desde el trabajo artístico» publicado en el catálogo Exercicis de memòria/Ejercicios de memoria, La Panera, Lleida, 2011. 
Si se piensa detenidamente, las razones por las que en España se ha prestado escasa atención a estos asuntos pueden encontrarse en la misma historia reciente de este país. Y en el papel que han desempeñado alguno de los agentes de las diversas instituciones artísticas (museos, centros de arte, universidades, comisarios, críticos...) que han pasado por alto unos planteamientos artísticos que forzosamente acarreaban pólvora de alto voltaje político. La animadversión, entre muchos sectores, a un arte con intención política no deja lugar a dudas. Ana Navarrete recuerda que Carmen Giménez en 1984 afirmó en el catálogo de la exposición Arte español actual, itinerante por Francia que: «Hoy, donde afortunadamente el arte político ya no está de moda, es urgente repensar una política del arte ${ }^{12}$ ¿A qué política se refería la entonces muy poderosa e influyente Carmen Giménez, responsable ministerial para las artes en los gobiernos de Felipe González? No deja de resultar paradójico que la «política del arte» mencionada se sostenía sobre la base de criterios relativos a la idea de éxito y de presencia mediática de la imagen de España en el circuito internacional del arte, un objetivo que podría parecer encomiable, dado el desconocimiento de la cultura española contemporánea en el exterior, pero que se fue fraguando a base de fomentar una concepción del arte despolitizada, acrítica y formalista.

Las instituciones, todavía entonces con infraestructuras precarias, estuvieron centradas durante gran parte de los ochenta y principios de los noventa en ponerse al día en lo relativo a dar a conocer al público aquellas tendencias y corrientes ausentes de los museos y centros de arte durante los años del franquismo y la transición, además de abrazar los lenguajes de moda. A ello se dedicó Carmen Giménez. Una puesta al día que se quiso asimismo despolitizada y que buscaba a toda costa traer a un país atrasado los discursos hegemónicos del arte internacional. Por ello el estudio, la exploración e investigación de fragmentos o episodios de la historia del estado español no podía sino incomodar. Estas prácticas críticas eran consideradas provincianas y además implicaba abordar trabajos de artistas que habían hurgado en asuntos espinosos mal zanjados con la ley de Amnistía de 1977.

La imagen que de la cultura artística española se quería proyectar, y eso pudo palparse en los fastos de la exposición de 1992 en Sevilla (de problemático y colonial nombre: V Centenario del Descubrimiento de América), había de aspirar a una equiparación con las representaciones más asentadas en el mercado internacional.

Las producciones artísticas de carácter cuestionador que indagasen en algunos aspectos relativos a la historia nacional o local, y que no fueron visiones coloristas y desustanciadas pasaron claramente desapercibidas. La marca España durante unos años estuvo fagocitada casi exclusivamente por la presencia internacional de la pintura de Miquel Barceló, un artista reivindicable desde criterios magnificadores del creador genial. Otros/as artistas que tuvieron eco allende los Pirineos también se vie-

12 Citado también por MARZO Jorge Luis en su texto: «El ¿triunfo? de la ¿nueva? pintura española de los 80», publicado en Toma de partido. Desplazamientos. Libros de la QUAM, Barcelona, 1995, pp.126-161. 
ron vinculados a estas apreciaciones despolitizadas: es el caso de Susana Solano, Cristina Iglesias, Juan Muñoz. El eje de mayor énfasis político lo encarnaban proposiciones de artistas nacidos en el estado español pero claramente ubicados en el exterior, sobre todo en Estados Unidos, en particular Antoni Muntadas, Francesc Torres, o en Francia Joan Rabascall, pues los que trabajaban aquí como, verbigracia, Francesc Abad, no contaban con apoyo mayoritario. En ese orden de cosas llama la atención que una de las iniciativas artísticas con la que se intentó dar un salto por encima del arte adocenado y conformista de la nueva figuración madrileña defendida por críticos como Juan Manuel Bonet o Francisco Calvo Serraller ${ }^{13}$ tuviera lugar fuera de España, concretamente en Ámsterdam. Me refiero a Antes y después del entusiasmo, concebida por José Luis Brea, en 1989. En este proyecto, que no puede equipararse con planteamientos posteriores, verbigracia los propuestos en $D e-$ sacuerdos ${ }^{14}$, de fondo directamente político, aparecen ya algunos nombres capitales para entender un conjunto de lenguajes ajenos a la pintura acomodaticia de principios de los 80 (transvanguardista y neo-expresionista). Entre ellos descuellan Rogelio López Cuenca, Pepe Espaliú y Pedro G. Romero. Este proyecto supuso de algún modo el rescate de la obra (olvidada por conceptual) de Isidoro Valcárcel-Medina, Juan Hidalgo y Joan Brossa, todos ellos artistas de fuerte impronta conceptualista aunque con especificidades propias. Entre un proyecto y otro, es decir el de Brea y el colectivo de Desacuerdos (en el que estuvieron presentes mentes pensantes como Pedro G. Romero, Jesús Carrillo, Manuel Borja-Villel, Santiago Eraso, Yolanda Romero, Marcelo Expósito, entre otros, y en el que faltó sin duda un mayor contingente de mujeres), es fundamental evocar la exposición diseñada por Mar Villaespesa bajo el título El sueño imperativo ${ }^{15}$, en 1991. En ella, junto a algunos artistas extranjeros, se puso de manifiesto el trabajo desmitificador de las imágenes basado en una ética de la resistencia de, entre otros, Francesc Abad, Francesc Torres, Rogelio López Cuenca y Pedro G. Romero. Mar Villaespesa, una de las voces fundamentales en la crítica de arte española, proseguiría su interés hacia los discursos críticos con su aportación feminista titulada $100 \%$, que pudo verse en Sevilla y en Málaga en 1993, en un contexto de feroz machismo.

La despolitización de la producción artística española no recae únicamente en la citada Giménez. De hecho defender el arte más amable y querido por el mercado es también una operación política (y económica). Es larga la lista de críticos de arte que contribuyeron sobremanera al menosprecio o desdén hacia todo aquello que oliese a político y a conceptual (el uso del vídeo se convirtió en anatema para los adalides de la pintura y la escultura) fuese cual fuese la complejidad estética postulada. Insisto en citar dos nombres: los de Francisco Calvo Serraller y

\footnotetext{
${ }_{13}$ Ambos críticos han capitaneado el desdén hacia los postulados conceptualistas que se dieron en España en los años setenta, particularmente en Cataluña.

14 Desacuerdos. Sobre arte, políticas y esfera pública en el Estado español, un proyecto de investigación y con dimensión expositiva en coproducción entre el Macba, UNIA, Arteleku y el Centro José Guerrero, que se inició en 2003. Se trata de una ambiciosa iniciativa colectiva, plasmada también en la publicación de siete boletines a día de hoy, que tuvo mucho eco mediático y algunas polémicas.

15 El sueño imperativo, Círculo de Bellas Artes, Madrid, 22 de enero-3 de marzo de 1991.
} 
Juan Manuel Bonet ${ }^{16}$, (aunque hay sin duda otros) por su posición de poder y privilegio en la institución-Arte, como se demuestra con las exposiciones que han comisariado y los artículos que escribían con un claro partis-pris anti-conceptual en los periódicos más influyentes (El País, sobre todo). Esto no supone afirmar que ambos mantuvieran las mismas posturas intelectuales.

La ansiada internacionalización del arte español era en el fondo una búsqueda de reconocimiento del mercado, de ahí que uno de los objetivos fundamentales de estas operaciones, ya en tiempos democráticos, fue la organización de la feria de arte Arco.

Por otro lado, en el ámbito universitario, pese a las aportaciones sobre arte social defendidas por historiadores como Valeriano Bozal, Inma Julián ${ }^{17}$ y Simón Marchán-Fiz, que deparan significativos matices unas respecto de otras, no puede decirse que las representaciones acerca de la violencia de la guerra civil y de la dictadura tuvieron una cálida acogida. Una excepción tuvo lugar en la Bienal de Venecia de 1976. Me refiero a la exposición (y publicación) España. Vanguardia artística y realidad social. $1936-1976{ }^{18}$. Bien es cierto que a medida que nos alejábamos temporalmente de la dictadura la amnesia se ha ido sedimentando en los estamentos artísticos académicos.

El paso del tiempo y el asentamiento de una lectura unívoca de los aspectos políticos más comprometidos de la transición — glorificada por Victoria Prego en su documental televisivo de 1995 - tuvo, también en el arte, un efecto hipnótico de modo que historiadores más jóvenes o los ya citados dejaron en barbecho o intacto el análisis de la producción artística sobre los asuntos que me ocupan en este texto en busca de terrenos menos pantanosos.

En ese sentido y debido a todas las insuficiencias indicadas pensé que era más que oportuna la realización de un proyecto expositivo que, sin ánimo alguno de exhaustividad, pudiera contribuir al debate que en los últimos años parece haberse despertado sobre la memoria histórica ${ }^{19}$ con todos los inconvenientes que pudiera

${ }^{16}$ Curiosamente Juan Manuel Bonet, junto a otros (Antonio Bonet Correa. Gabriel Ureña, Sofía Diéguez, Doménech Font, Carmen Grimau y Juan Antonio Ramírez), participó en la publicación Arte del franquismo, Madrid, Cátedra, 1981. Es decir, seis años después de la muerte del dictador.

17 Inma Julián, «El cartelismo y la gráfica en la guerra civil» en BOZAL Valeriano y LLORENS Tomás (eds) España. Vanguardia artística y realidad social. 1936-1976, Barcelona, Gustavo Gili, 1976.

18 Según información publicada por Santiago Amón en El País, 8 de mayo de 1976: «La elaboración del proyecto ha corrido a cargo de una Comisión, integrada por Antoni Tàpies, Antonio Saura, Agustín Ibarrola y el Equipo Crónica (pintores); el arquitecto Oriol Bohigas, el grafista Alberto Corazón, los historiadores Tomás Lloréns y Valeriano Bozal, con la asistencia del arquitecto Víctor Pérez Escolano, la profesora Inmaculada Julián, el pintor Josep Renau y el fotógrafo José Miguel Gómez, ejerciendo funciones coordinadoras, a título de secretario, Mantiel García García».

19 Importa citar el proyecto ideado por Virginia Villaplana titulado El instante de la memoria, en formato de exposición, novela documental, talleres y ciclos de conferencias y vídeos, que pudo plasmarse en la muestra de Off-limits y en un ciclo en el MNCARS, Madrid, 2010. Asimismo es de interés el número 35, abril 2008, de la revista Exit Express con el título «Pretérito imperfecto. Memoria y arte contemporáneo», con textos de Manuel Cruz, Miguel Morey, Pedro G. Romero y Francesc Torres y que incluye asimismo una entrevista con Rogelio López Cuenca. 
acarrear dicha denominación. Por ello puse en marcha en La Panera, Lleida, la exposición titulada Ejercicios de memoria que pudo verse entre el 26 de enero y el 25 de abril de 2011, con la ayuda inestimable de Glòria Picazo y su equipo.

Con esta muestra he buscado reunir algunas de las manifestaciones artísticas en las que afloran lecturas y revisiones de la historia de la guerra civil y del franquismo, a través de la producción de imágenes y de ficciones sobre ellas. La historia más reciente también ha estado presente en tanto que las políticas actuales sobre la memoria cuando se han producido (bajo el gobierno de José Luis Rodríguez Zapatero) han suscitado todo tipo de reacciones, algunas también entre los/as propios /as creadores/as.

En Ejercicios de memoria se presentaron obras en distintas disciplinas (vídeo, fotografía, objetos) que posibilitaron que se reflexionara sobre distintos asuntos (la dificultad de evocar recuerdos dolorosos, la necesidad de recuperar a los desaparecidos y el homenaje debido a los represaliados asesinados en las fosas comunes, la omisión del papel de las mujeres en el pasado traumático, el exilio, la violencia perpetrada por grupos políticos de distinto signo, la brutal represión franquista a lo largo de los años, inclusive en el período agónico del mandato de Franco (la ejecución de Puig Antich), el papel de algunos grupos de izquierda en la comisión de actos luctuosos durante la guerra...

Con este proyecto no pretendía cerrar ninguna disputa ni buscaba llegar a consensos ni a uniformidades de pensamiento sino, más bien, trataba de dar paso a discusiones largamente postergadas y a una proliferación de ideas que contribuyera a conocer la historia pasada y la producción de discursos, representaciones e imágenes.

En ese sentido he de decir que los mayores frutos cosechados por la exposición, y las actividades organizadas en torno a la misma, provienen de aquellos sectores de la población leridense que ha acudido a las mismas, particularmente algunos grupos de estudiantes de la universidad de Lleida. Salvo alguna excepción puedo afirmar que la prensa naciona ${ }^{20}$ - y la crítica de arte que escribe en los distintos mediosha ignorado la exposición. Las razones son muchas y variadas (el lugar periférico de Lleida en el contexto catalán, la vagancia de los críticos que no se desplazan fuera de los centros de poder mediático - Madrid, en particular, y Barcelona- a menos que se les paguen los gastos, la falta de sensibilidad por los temas tratados y otros pretextos...). Es un motivo para la reflexión lo que me lleva a insistir sobre la pertinencia de la siguiente frase del director de Documenta XII, Roger M. Buergel, que afirmó:

«El problema general de España es que nunca ha habido una ruptura con el pasado. Entre el franquismo y la democracia todo fue demasiado fácil, tranquilo, reposado...y ARCO es el ejemplo perfecto de esta «transición apacible», que cubre

20 A fecha de hoy, 26 de julio de 2011, el artículo de mayor enjundia publicado sobre la exposición lo escribió Miquel Bardagil. Se trata de «Recuperació del passat», $L$ avenç. Barcelona, № 366, marzo de 2011, pp. 68-69. 
todas las cuestiones problemáticas bajo una gris alfombra de convenciones ${ }^{21}$

A este aserto podríamos contraponer esta reflexión más reciente de Rogelio López Cuenca:

«El pasado está presente siempre y es lo que configura el presente. Yo lo uso continuamente para poder justificar el presente y para poder imaginar el futuro. Ahora mismo me parece que ser progresista es mirar muchísimo al pasado»22.

Comparto el fondo de lo propuesto por López Cuenca pero me temo que estas ideas no tienen muchos seguidores o acaso hay pocos artistas progresistas en la actualidad. ¿De qué forma, con qué ángulo se ha mirado a los tiempos de la guerra civil y la dictadura en el estado español desde la dimensión artística? Desde la perspectiva de hoy se puede aseverar que a finales de los ochenta afloran las primeras manifestaciones críticas respecto no sólo del lejano pasado de la guerra civil sino también de los crímenes últimos del franquismo. Ahí están desde planteamientos harto disímiles las creaciones de Joan Brossa y Francesc Torres.

En El convidat, 1986-1990, con el perverso ingenio que le caracterizaba, el poeta catalán articuló un contundente assemblage visual: por un lado, una mesa vestida de mantel blanco, candelabro, vino, botella de champán y un ramo de flores, y por otro un garrote de oscura madera. En la mesa sólo hay cubiertos para una persona, el reo que será vilmente agasajado antes de la ejecución. Diez años antes de la realización de esta pieza Brossa había escrito un soneto dedicado a Salvador Puig Antich en su Antologia de poemes de revolta. El asesinato de Puig Antich había suscitado, dentro y fuera del estado español, múltiples condenas y convocatorias de manifestaciones de solidaridad. El artista Marcelo Expósito, que incluyó imágenes del joven catalán junto a otras de Heinz Chez en Los demonios familiares, 1990-94, discurre al respecto:

«Supongo que Puig Antich ha servido durante mucho tiempo (en el campo militante, en la historiografía académica de izquierda, en ciertas áreas de la cultura popular) como metonimia de los crímenes de un régimen cuyos aparatos hicieron concesiones democratizadoras a cambio de -entre otras cosas - impunidad retrospectiva. Eso supongo que significaba el signo «Puig Antich» también para mí: una metonimia de la represión franquista ejercida sobre la declinación que los proyectos revolucionarios sesentayochistas adoptaron en nuestro territorio (...) ${ }^{23}$

También a finales de los ochenta, concretamente en 1988, en Estados Unidos, Francesc Torres, uno de los artistas más atentos y dedicados a las distintas parcelas de la historia traumática española, concibió Belchite/South Bronx. A Trans-

21 Roger M. Buergel, entrevistado por Alberto Sánchez Balmisa, Exit Express, no 22, Madrid, 2006, p. 7.

22 Entrevista a Rogelio López Cuenca, Exit Express, no 35, Madrid, abril 2008, p. 10.

${ }^{23}$ Extraído de la entrevista con Marcelo Expósito inserta en Ejercicios de memoria, La Panera, Lleida, 2011, pp. 48-49. 
Cultural and Trans-Historical Landscape que mostró en la Universidad de Massachussets.

Como afirmó el propio Torres se trataba de un proyecto que ampliaba otro anterior con los que se proponía establecer un paralelismo entre un espacio arquitectónico de un tiempo de guerra con otro en momentos de paz. La comparación quedaba establecida entre Belchite - una población aragonesa que cayó en manos fascistas al inicio de la guerra civil y que fue recuperada por los republicanos, entre los que se encontraba la brigada Abraham Lincoln, para volver a ser recapturada por los golpistas- y el barrio del South Bronx, un verdadero despojo urbano y zona de tensiones raciales en Nueva York.

Así, en este intento por ofrecer una meditación acerca de la transversalidad de la memoria, Torres tuvo el mérito de volver su mirada hacia un lugar fundamental de la historia de España, un espacio que «produce la sensación de tiempo suspendido ${ }^{24}$, como interrumpido, casi borrado, estaba el estudio del pasado en el campo del arte.

Torres volvió a fijarse en Belchite tras conocer que las ruinas del pueblo zaragozano eran el escenario elegido por el director Terry William para filmar The Adventures of Baron Munchausen. Al llegar a la población, pudo observar los restos de atrezo esparcidos entre las ruinas (elementos varios, accesorios, cadalso, cañones, estatuas de caballo...). Este conjunto de decorados del último día de rodaje de la película creaban un efecto desnaturalizador, más todavía si cabe, pues fundían épocas distantes e imaginarios y fábulas diferentes, impidiendo restituir los hechos históricos allí ocurridos. Como escribió ácidamente Torres «el pueblo parecía un cadáver maquillado y vestido de payaso". La experiencia in situ constituiría la base de un conjunto fotográfico posterior titulado La visita de Munchausen, 2007.

La reconstrucción ya no de un espacio, de un lugar, sino de una experiencia humana, de un tiempo de espanto y muerte, en concreto la huida de miles de personas de la ciudad de Málaga debido a la llegada de las tropas fascistas constituye la médula del proyecto ideado en 2007 por Rogelio López Cuenca. Se trata de Málaga, 1937. Nunca más, una propuesta colgada hoy de su web en la que conviven imágenes de archivo, valiosos textos como los del doctor canadiense Norman Bethune, testigo del horror, sonidos en distintas lenguas, junto a las voces de algunos de los sobrevivientes presentes en un vídeo creado por López Cuenca en el que reviven el recuerdo de los bombardeos efectuados desde barcos y aviones por italianos y alemanes mientras caminaban a duras penas por la carretera de la costa hacia Almería. Además de este valioso trabajo Rogelio López Cuenca, con la colaboración de Santiago Cirugeda, diseñó un espacio conmemorativo en Torre del

24 TORRES, Francesc «El fuego absoluto/Absolute Fire» en el catálogo Belchite/South Bronx. A Trans-Cultural and Trans-Historical Landscape, University Gallery, University of Massachussets at Amherst, 1988, p. 78. 
Mar (Vélez-Málaga), en homenaje a las víctimas del éxodo de la carretera de Málaga a Almería. Se trata de un proyecto materializado que trata de huir de la plasmación de un monumento grandilocuente al uso al evitar reproducir un obelisco, un pedestal o un monolito.

El vídeo es también el dispositivo empleado preferentemente por Marcelo Expósito. En El año en que el futuro acabó (comenzó), 2007, una concatenación de imágenes encadenadas hacia atrás, se arranca del año 1977, fecha de las primeras elecciones habidas desde 1936, para engarzar con una serie de relatos, imágenes y hechos políticos que explicarían los cimientos con que se fraguó la transición. Este periodo, ahora sometido a revisión y a examen, a veces de forma agitada, es objeto de la mirada de María Ruido en Plan Rosebud (La escena del crimen y Convocando a los fantasmas), 2008. Se trata de un ambicioso trabajo que hace un guiño a Orden Welles en el título y que se compone de dos extensos vídeos (dos horas de duración cada uno) en los que se entreveran las opiniones de reputados historiadores junto a los puntos de vista de ciudadanos anónimos que, a veces con vehemencia, a veces con temple, se expresan ante sucesos tales como la retirada de estatuas de Franco (en el Ferrol) o el sentido/sinsentido de homenajes al dictador en el Valle de los Caídos, entre otras materias. El prisma utilizado permite contrarrestar las lecturas oficiales dando voz a colectivos feministas y de homosexuales y lesbianas que tuvieron un papel destacado en la transición.

Ruido aprovecha este proyecto para cuestionar la banalización y turistización de algunas iniciativas supuestamente bien intencionadas de recuperación de la memoria histórica, por ejemplo la del lazareto de la isla de San Simón, en la ría de Vigo, en este caso una iniciativa de gobiernos progresistas. Y lo hace sin perder de vista ejemplos de otros países como Francia y Gran Bretaña que también se han enfrentado a la búsqueda de métodos y procedimientos de transmisión de la memoria, cayendo a veces en la creación hueca y espectacular de parques temáticos.

Con Ejercicios de memoria traté de no caer en planteamientos sectarios de ahí que intentase evitar la apuesta por una sola línea artística. En ese sentido y muy alejado de las proposiciones documentales de Ruido, se sitúa el trabajo de Fernando Sánchez Castillo, fascinado y preocupado a la par por los obstáculos que distintas instituciones españolas del estado ponen ante el conocimiento del legado monumental de las incómodas estatuas del dictador retiradas, a veces de modo vergonzante, de distintas ciudades españolas. Sánchez Castillo parece preguntarse: ¿deben estar en un museo, ser accesibles al público o dormir el sueño de los in/justos en las dependencias militares de cualquier Capitanía general? Este celo protector exagerado es el que Sánchez Castillo observa en algunas personas formadas en la España democrática pero que se comportan todavía con modos autoritarios ${ }^{25}$.

25 Véase las respuestas del artista al cuestionario publicado en Ejercicios de memoria, La Panera, Lleida, 2011, pp 120-126. 


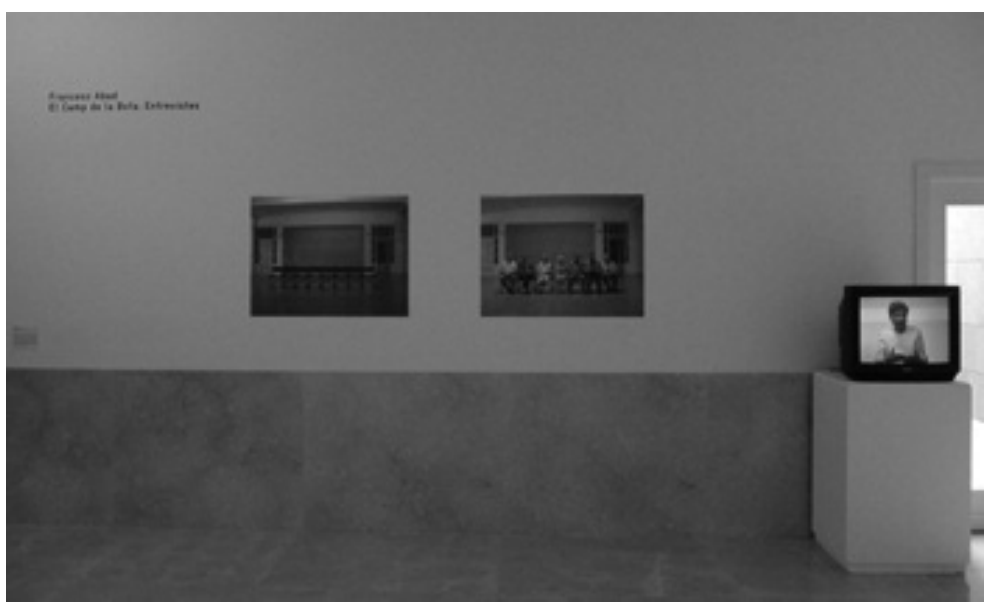

1.- Vista de la exposición Ejercicios de memoria. La Panera, Lleida, 2011

La existencia de trabas, evidenciada en distintas ocasiones, dan a entender la inmadurez de la clase política española, inclusive del gobierno socialdemócrata de Zapatero, que ha llevado discretamente algunas de sus decisiones que afectan a la memoria histórica para soslayar reacciones virulentas de la derecha montaraz (el Partido Popular y la jerarquía de la Conferencia Episcopal, y las numerosos páginas web de ultraderecha de modo destacado) que a mi juicio no ha roto todavía el cordón umbilical con tiempos pasados.

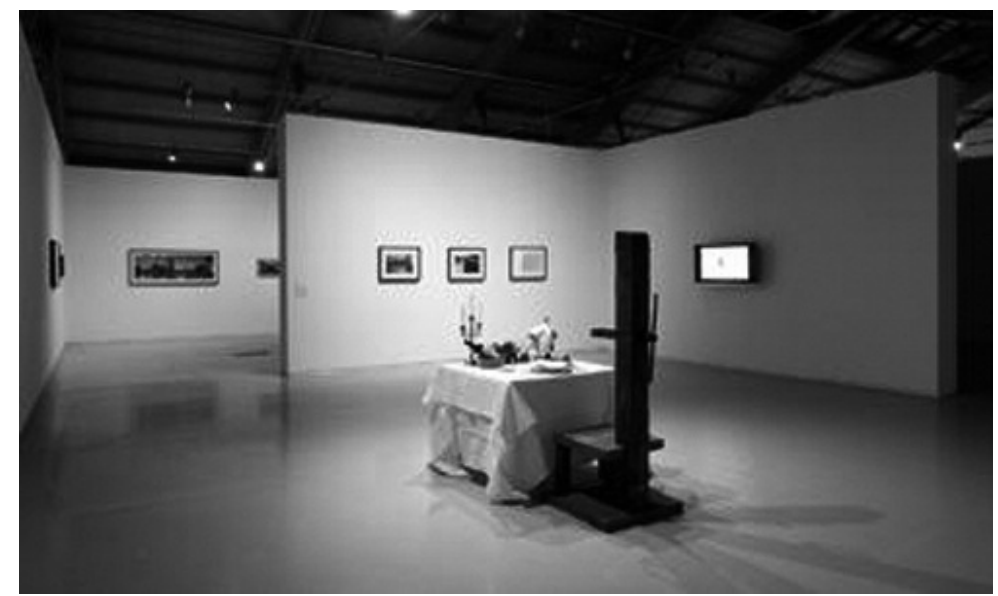

2.- Vista de la exposición Ejercicios de memoria. La Panera, Lleida, 2011. En el centro Joan Brossa, El convidat, 1986

Sin ánimo alguno de comparar la labor perniciosa de los llamados pseudo-historiadores, que eluden intencionadamente cuestionarse la falta absoluta de legiti- 
midad de las políticas franquistas, existen asimismo algunos sectores de la izquierda a los que desagrada reconocer hechos funestos perpetrados durante la guerra por grupos revolucionarios. De ahí que me pareciera pertinente invitar a la exposición a Pedro G. Romero que ha desvelado algunos de ellos en sus proyectos sobre las chekas de Barcelona. De estas celdas de castigo, que no sólo existieron en Cataluña (las hubo también en Madrid y Valencia...) a Romero le ha interesado sobremanera conocer el porqué de la utilización de colores, formas y materiales empleados por las vanguardias abstractas que se usaron en las checas con una finalidad claramente desestabilizadora. Los colores mareantes y la estrechez del espacio ayudaban a romper la resistencia de los reos sometidos a torturas y actos de violencia. Lo que habían sido promesas liberadoras de la modernidad se aplicaban aquí al servicio de la destrucción del enemigo.

Esta semiocultación o disimulo de la violencia revolucionaria no es el único ejemplo pues hay muchos otros episodios, experiencias, vivencias, realizaciones y manifestaciones que a día de hora se ignoran, aunque sean de otro cariz. Destaparlos, descubrirlos, en el caso del papel desempeñado por las mujeres durante los años treinta y en la posguerra, es la meta de Ana Navarrete en Nadie se acuerda de nosotras mientras estamos vivas. Muerte, regresión y exilio (1931-1941), una investigación en curso que permite mediante la red reconstruir el recorrido vital, intelectual, político de mujeres tales Carlota O Neill, Lucía Sánchez Saornil, Carmen de Burgos..., que se han vuelto invisibles gracias a una visión canónica, patriarcal y machista que ha imperado también en los estudios sobre la guerra civil y el fascismo. Si Navarrete habla de personas con nombres y apellidos, la también valenciana Ana Teresa Ortega busca en cambio recuperar, poner en imágenes, fotografiar aquellos espacios, cerrados o al aire libre, que sirvieron de campos de internamiento y de concentración de los presos represaliados por la dictadura durante la guerra y en tiempos posteriores. Tras estudiar a conciencia en distintos archivos (Alcalá de Henares, Salamanca.... ${ }^{26}$, Ana Teresa Ortega pudo comprobar que la existencia de estos campos respondía a un diseño definido, fríamente calculado, preparado de antemano, de traslados de presos, de fusilamientos.

Estamos ante una práctica ésta que fue más habitual de lo que parece a simple vista y que ha llevado a Francesc Abad a desenterrar del olvido, tras años de denuedo y empujado por una voluntad de hierro (dado el ímprobo esfuerzo que supuso el proyecto), a quienes fueron asesinados en El Camp de la Bota (título de su proyecto) entre 1939 y 1952. Y lo ha hecho recorriendo diferentes poblaciones de Cataluña, recogiendo testimonios personales e información gráfica, realizando entrevistas a familiares de las personas fusiladas. No era ésta sin embargo la primera vez en que Abad hurgaba en las heridas abiertas del pasado. La memoria, en sus distintas vertientes, le ha guiado a lo largo del tiempo, vista sobre todo desde la óptica benjaminiana a quien dedicó su trabajo Spuren, en 1988.

${ }^{26}$ Véase el catálogo que recoge las fotografías de Ana Teresa Ortega, Cartografías silenciadas. Espacios de represión franquista, Valencia, Universitat de València, 2010. 
Si Abad ha optado por un procedimiento que requería de la participación colectiva para recuperar una memoria desaparecida, Montserrat Soto, que contó con el apoyo de la Asociación para la recuperación de la memoria de Burgos, ha optado por una inflexión más personal. Soto, como otras personas en España, andaba buscando a su abuelo, de cuyo cadáver nada se sabía hasta que fue hallado en una fosa común en Villamayor de los Montes. Una fosa que se cerró en 1936 y no se reabriría hasta julio de 2004. De resultas de su visita a otro pueblo burgalés, Gumiel de Izán, para reclamar los restos, Montserrat Soto decidió realizar un vídeo titulado Memoria oral. Secreto 1. Dos elementos principales lo vertebran: por un lado, una sucesión de voces que recuerdan hechos luctuosos y, por otro, las imágenes de una mujer mayor que camina por los alrededores de la fosa con rostro entristecido, llegando incluso a tumbarse sobre la tierra como si anhelase sentir el respirar de quien ya no está en vida. En un momento determinado del vídeo una voz alude a la imposibilidad durante años de hablar libremente de los asesinatos perpetrados: «Estas cosas no salían de casa», se dice. Ahora, por fin, parece que ya lo han hecho. Pero este gesto, este acto que significaba un consuelo para los familiares y parientes de Soto no estará completo hasta que todos los que sufrieron las atrocidades de la guerra y la violencia de la dictadura franquista no hallen semejante alivio y también justicia. Y así el pasado dejará de ser punzante. 
